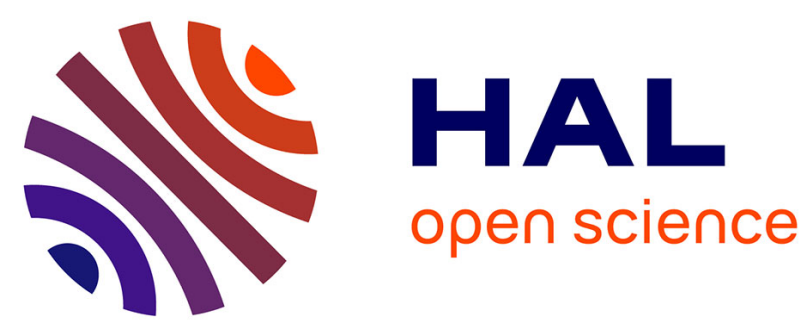

\title{
Single kernel analysis of fumonisins and other fungal metabolites in maize from South African subsistence farmers
}

Jesper Mølgaard Mogensen, Stine Mørcholdt Sørensen, Michael Sulyok, Liana van Der Westhuizen, Gordon Shephard, Jens Christian Frisvad, Ulf Thrane, Rudolf Krska, Kristian Fog Nielsen

\section{To cite this version:}

Jesper Mølgaard Mogensen, Stine Mørcholdt Sørensen, Michael Sulyok, Liana van Der Westhuizen, Gordon Shephard, et al.. Single kernel analysis of fumonisins and other fungal metabolites in maize from South African subsistence farmers. Food Additives and Contaminants, 2011, pp.1. 10.1080/19440049.2011.611823 . hal-00744827

\section{HAL Id: hal-00744827 \\ https://hal.science/hal-00744827}

Submitted on 24 Oct 2012

HAL is a multi-disciplinary open access archive for the deposit and dissemination of scientific research documents, whether they are published or not. The documents may come from teaching and research institutions in France or abroad, or from public or private research centers.
L'archive ouverte pluridisciplinaire HAL, est destinée au dépôt et à la diffusion de documents scientifiques de niveau recherche, publiés ou non, émanant des établissements d'enseignement et de recherche français ou étrangers, des laboratoires publics ou privés. 


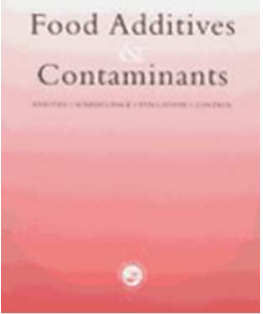

\section{Single kernel analysis of fumonisins and other fungal metabolites in maize from South African subsistence farmers}

\begin{tabular}{|c|c|}
\hline Journal: & Food Additives and Contaminants \\
\hline Manuscript ID: & TFAC-2011-122.R2 \\
\hline Manuscript Type: & Original Research Paper \\
\hline $\begin{array}{r}\text { Date Submitted by the } \\
\text { Author: }\end{array}$ & 13-Jul-2011 \\
\hline Complete List of Authors: & $\begin{array}{l}\text { Mogensen, Jesper; Tecnical university of Denmark } \\
\text { Sørensen, Stine; Technical University of Denmark, Department of } \\
\text { Systems biology } \\
\text { Sulyok, Michael; University of Natural Resources and Applied Life } \\
\text { Sciences Vienna, Center for Analytical Chemistry, Department IFA-Tulln } \\
\text { van der Westhuizen, Liana; MRC, PROMEC Unit } \\
\text { Shephard, Gordon; Medical Research Council, PROMEC Unit } \\
\text { Frisvad, Jens } \\
\text { Thrane, Ulf; Technical University of Denmark, DTU Systems Biology } \\
\text { Krska, Rudolf; University of Natural Resources and Applied Life Sciences, } \\
\text { Vienna, Department for Agrobiotechnology (IFA-Tulln), Christian Doppler } \\
\text { Laboratory for Mycotoxin Research } \\
\text { Nielsen, Kristian; Technical University of Denmark, DTU Systems Biology }\end{array}$ \\
\hline Methods/Techniques: & LC/MS, Mycology \\
\hline Additives/Contaminants: & Fumonisins \\
\hline Food Types: & Cereals \\
\hline Abstract: & $\begin{array}{l}\text { Fumonisins are important Fusarium mycotoxins mainly found in maize } \\
\text { and derived products. In this study, we analyzed maize from five } \\
\text { subsistence farmers in the former Transkei region of South Africa. } \\
\text { Farmers had sorted kernels into good and mouldy quality. A total of } 400 \\
\text { kernels from } 10 \text { batches were analyzed; of these } 100 \text { were visually } \\
\text { characterized as uninfected and } 300 \text { as infected. Of the } 400 \text { kernels, } 15 \% \\
\text { were contaminated with } 1.84-1428 \mathrm{mg} / \mathrm{kg} \text { fumonisins, and } 4 \%(\mathrm{n}=15) \\
\text { had fumonisin content above } 100 \mathrm{mg} / \mathrm{kg} \text {. The total fumonisin } \\
\text { concentration was } 0.28 \neg-1.1 \mathrm{mg} / \mathrm{kg} \text { for good-quality batches and } 0.03- \\
6.2 \mathrm{mg} / \mathrm{kg} \text { for mouldy-quality batches. The high average fumonisin } \\
\end{array}$ \\
\hline
\end{tabular}


highly contaminated kernels. Removing highly infected kernels ( $\sim 4 \%$ of the kernels) was estimated to reduce total fumonisin content by $71 \%$. Of the 400 kernels, 80 were screened for 186 microbial metabolites by liquid chromatography-tandem mass spectrometry, detecting 17 other fungal metabolites, including fusaric acid, equisetin, fusaproliferin, beauvericin, cyclosporins, agroclavine, chanoclavine, rugulosin and emodin. Fusaric acid in samples without fumonisins indicated the possibility of using nontoxinogenic Fusaria as biocontrol agents to reduce fumonisin exposure, as done for Aspergillus flavus. This is the first report of mycotoxin profiling in single maize kernels.

\section{SCHOLARONE ${ }^{m}$ \\ Manuscripts}




\title{
Single kernel analysis of fumonisins and other fungal metabolites in maize from
}

\section{South African subsistence farmers}

J.M. Mogensen ${ }^{a}$, S.M. Sørensen ${ }^{a}$, M. Sulyok ${ }^{b}$, L. van der Westhuizen ${ }^{c}$, G.S. Shephard ${ }^{c}$, J.C. Frisvad ${ }^{a}$, U. Thrane ${ }^{\mathrm{a}}$, R. Krska ${ }^{\mathrm{b}}$, K.F. Nielsen ${ }^{\mathrm{a}^{*}}$.

${ }^{a}$ Center for Microbial Biotechnology, Department of Systems Biology, Technical University of Denmark, Søltofts Plads 221, DK-2800 Kgs. Lyngby, Denmark

${ }^{\mathrm{b}}$ Department IFA-Tulln, University of Natural Resources and Life Sciences, Vienna, Konrad Lorenzstrasse 20, A-3430 Tulln, Austria

${ }^{\mathrm{c}}$ Programme on Mycotoxins and Experimental Carcinogenesis, PO Box 19070, Tygerberg 7505, South Africa.

*Corresponding author. Tel: +45 452526 02; Fax: + 45458841 48; E-mail: kfn@bio.dtu.dk

\begin{abstract}
Fumonisins are important Fusarium mycotoxins mainly found in maize and derived products. In this study, we analyzed maize from five subsistence farmers in the former Transkei region of South Africa. Farmers had sorted kernels into good and mouldy quality. A total of 400 kernels from 10 batches were analyzed; of these 100 were visually characterized as uninfected and 300 as infected. Of the 400 kernels, $15 \%$ were contaminated with $1.84-1428 \mathrm{mg} / \mathrm{kg}$ fumonisins, and $4 \%$ ( $\mathrm{n}=15$ ) had fumonisin content above $100 \mathrm{mg} / \mathrm{kg}$. None of the visually uninfected maize had detectable amounts of fumonisins. The total fumonisin concentration was $0.28-1.1 \mathrm{mg} / \mathrm{kg}$ for good-quality batches and $0.03-6.2 \mathrm{mg} / \mathrm{kg}$ for mouldy-quality batches. The high fumonisin content
\end{abstract}


in the batches was apparently caused by a small number (4\%) of highly contaminated kernels, and removal of these reduced the average fumonisin content by $71 \%$. Of the 400 kernels, 80 were screened for 186 microbial metabolites by liquid chromatography-tandem mass spectrometry, detecting 17 other fungal metabolites, including fusaric acid, equisetin, fusaproliferin, beauvericin, cyclosporins, agroclavine, chanoclavine, rugulosin and emodin. Fusaric acid in samples without fumonisins indicated the possibility of using non-toxinogenic Fusaria as biocontrol agents to reduce fumonisin exposure, as done for Aspergillus flavus. This is the first report of mycotoxin profiling in single naturally infected maize kernels.

Keywords: fumonisin, mycotoxins, maize, Fusarium

\section{Introduction}

Fumonisins are a group of naturally occurring, polyketide-derived mycotoxins produced mainly by Fusarium verticillioides and Fusarium proliferatum (Rheeder et al. 2002). Recently, fumonisins $B_{2}$ and $\mathrm{B}_{4}\left(\mathrm{FB}_{2}, \mathrm{FB}_{4}\right)$ were also detected in Aspergillus niger (Frisvad et al. 2007b; Noonim et al. 2009) and Tolypocladium (Mogensen et al. 2010a). Fumonisin production has also been detected in a single strain of Alternaria arborescens (as Alternaria alternata f. sp. lycopersici) (Chen et al. 1992) that has since lost this ability (Solfrizzo et al. 2005). Fumonisins are an important health risk because they are potentially carcinogenic and cause toxicoses in humans and animals (Sydenham et al. 1991). The effects of fumonisins include outbreaks of equine leukoencephalomalacia, and porcine pulmonary oedema and hydrothorax (Harrison et al. 1990; Thiel et al. 1991). Fusarium species occur worldwide in maize, where they infect the cob during flowering. They can produce high amounts of fumonisins in tropical and subtropical regions (Marasas 2001; Reddy et al. 2009; Shephard et al. 1996) whereas in colder regions, the fumonisin contamination is much 
lower (Logrieco et al. 2002; Miller 2008). In addition to maize-derived products, fumonisins have also been detected in rice (Yazar \& Omurtag 2008), black tea leaves (Martins et al. 2001), asparagus (Logrieco et al. 1998), and pine nuts (Marin et al. 2007). Recently A. niger has been shown to be the source of fumonisins in wine and raisins (Knudsen et al. 2010; Logrieco et al. 2010; Mogensen et al. 2010b). Because of their ubiquitous natural occurrence in maize and maizebased foods (Shephard et al. 1996), fumonisins have attracted considerable global attention from food safety authorities. Consequently, international consultations and risk assessments have resulted in the US Food and Drug Administration (USFDA) recommending a maximum level in maize for human consumption of $2-4 \mathrm{mg} / \mathrm{kg}$ total fumonisins depending on the maize product (US Food and Drug Administration 2001), and the European Union (EU) setting a regulatory limit of $0.2-2 \mathrm{mg} / \mathrm{kg}$ (EU 2007).

Maize is the staple cereal food grown and consumed by the rural farming communities of Africa, especially in the Transkei region in South Africa (Shephard et al. 2002), where the effects of fumonisins were first discovered. The Transkei region has one of the highest incidences of oesophageal cancer in the world, which seems to be associated with the fumonisin intake (Makaula et al. 1996; Shephard et al. 2002).

Analysis of single kernels has been performed previously with different methodologies, for instance: GC-MS for ergosterol in wheat kernels (Dong et al. 2006), ELISA for deoxynivalenol in wheat kernels (Sinha \& Savard 1997) and DESI-MS for fumonisin in the surface of spiked maize kernels (Maragos \& Busman 2010).

In this study, we examined subsistence grown maize from the former Transkei region of South Africa sorted into high- and low-quality cobs by the farmers themselves. We surveyed the fumonisin content of single maize kernels to establish the effects of manual visual sorting and 
determine the levels of fumonisin in the single kernel. Since numerous kernels appearing infected did not contain fumonisins, further $20 \%$ of the analysed kernels were reanalyzed for 186 microbial metabolites by a multi-toxin method to detect compounds from non-fumonisin producing Fusaria as well as post-harvest contaminants as Penicillia and Aspergilli.

\section{Materials and Methods}

Unless otherwise stated, all solvents were high-performance liquid chromatography (HPLC)-grade and other chemicals were analytical-grade from Sigma-Aldrich (St. Louis, MO). Water was purified on a Milli-Q system (Millipore, Bedford, MA). Certified standard $\mathrm{FB}_{1}, \mathrm{FB}_{2}$ and $\mathrm{FB}_{3}$ were from Biopure (Tulln, Austria). Standards of $\mathrm{FB}_{4}$ and $\mathrm{FB}_{6}$ were from previous studies (Månsson et al. 2010).

\section{Maize samples}

Ten batches of maize ( $\sim 500 \mathrm{~g}$ ) were obtained from subsistence farmers in the Centane magisterial district of the former, Transkei region, South Africa. Five batches had been classified by the farmers who grew them, as high-quality cobs, good maize to be used for human consumption, and five as mouldy-quality (mouldy) maize cobs. The mean percentage of infected/damaged kernels of each batch was determined by counting infected kernels in a random selection of 100 .

\section{Isolation and identification of mycoflora}

Kernels were surface sterilized in $0.4 \%$ sodium hypochlorite for 2 minutes, then washed in sterile water. Six kernels were placed on each of the following media: dichloran $18 \%$ glycerol agar (DG18) (Hocking \& Pitt 1980), Czapek iprodione dichloran agar (CZID) (Abildgren et al. 1987), and potato- 
carrot-manganese agar (PCMA) (Sørensen et al. 2009). In addition, six visibly infected or damaged kernels from each batch were placed on $2 \%$ water agar, resulting in an overall analysis of 24 kernels per batch and a total of 240 kernels. Plates were incubated for 7 days at $25^{\circ} \mathrm{C}$ in darkness. Fusarium, Penicillium and Aspergillus species were sub-cultured onto media appropriate for the genus and identified as previously described (Frisvad et al. 2007a; Frisvad \& Samson 2004; Samson et al. 2006; Samson et al. 2010; Wulff et al. 2010), including secondary metabolite profiling and comparison to ex-type cultures (Nielsen \& Smedsgaard 2003).

\section{Extraction of kernels}

For each maize batch, kernels were divided into groups of undamaged/uninfected and damaged/infected. Based on visual inspection of each batch, 10 uninfected and 30 infected kernels were selected for chemical analysis, for a total of 400 kernels.

A single kernel was transferred to a $5-\mathrm{mL}$ cryotube containing 10 steel balls (diameter $=3 \mathrm{~mm}$ ) and $1.5 \mathrm{~mL}$ distilled water added. The cryotubes were shaken for 5 minutes by a Mini Bead-beater (Biospec Products Inc, Bartlesville, OK). Afterwards, $1.5 \mathrm{~mL}$ acetonitrile was added and the tubes were shaken on a shaking platform for 30 minutes. The mixture was centrifuged at $6000 \times g$ and $1.5 \mathrm{~mL}$ supernatant filtered through a $0.45-\mu \mathrm{m}$ polytetrafluoroethylene filter and used directly for analysis.

\section{LC-MS/MS fumonisin analysis}

Liquid chromatography tandem mass spectrometry (LC-MS/MS) was performed on a Quattro Ultima triple mass spectrometer (Micromass, Manchester, UK) with an electrospray ionization (ESI) source as previously described (Mogensen et al. 2010c). Separations were performed on a 
50-mm Gemini $\mathrm{C}_{6}$-phenyl column (Phenomenex, Torrance, CA), using an acidic linear gradient from $20 \%$ acetonitrile to $55 \%$ in $6 \mathrm{~min}$ at a flow rate of $0.3 \mathrm{~mL} / \mathrm{min}$. Tandem MS was performed in $\mathrm{ESI}^{+}$, with the MS in multiple reaction monitoring (MRM) mode (Mogensen et al. 2010b; 2010c).

Transitions were: $\mathrm{FB}_{2}$ and $\mathrm{FB}_{3} \mathrm{~m} / \mathrm{z} 706 \rightarrow 336$ and $706 \rightarrow 512 ; \mathrm{FB}_{4} \mathrm{~m} / \mathrm{z} 690 \rightarrow 320$ and $690 \rightarrow 514$; and $\mathrm{FB}_{1}$ and $\mathrm{FB}_{6} \mathrm{~m} / \mathrm{z} 722 \rightarrow 334$ and $722 \rightarrow 528$. A few extracts from kernels with the highest infection rate were additionally screened by LC-time-of-flight (TOF)-MS for other fumonisin analogues (Nielsen \& Smedsgaard 2003) Fumonisin extraction was validated by spiking single kernels of undamaged/uninfected maize. The kernels were split with a scalpel and spiked with fumonisin standards to final individual $\mathrm{FB}_{1}$ and $\mathrm{FB}_{2}$ concentrations of $6.7 \mathrm{mg} / \mathrm{kg}, 2.3 \mathrm{mg} / \mathrm{kg}, 0.75 \mathrm{mg} / \mathrm{kg}, 0.25 \mathrm{mg} / \mathrm{kg}$, and $0.081 \mathrm{mg} / \mathrm{kg}$. The kernels were air dried at room temperature for one hour before extraction. Experiments were performed in triplicate on three different days. The apparent recovery was calculated from acetonitrile:water (1:1)-diluted samples with similar concentrations of fumonisins.

\section{LC-MS/MS multi-mycotoxin screening}

From the 400 extracts analyzed for fumonisins, 80 were selected from the 10 batches to represent a combination of high, low, and no amounts of fumonisins. The 80 samples ( 8 from visually noninfected kernels and 72 from visibly infected or damaged kernels) were analyzed for 186 bacterial and fungal metabolites using a QTrap 4000 LC-MS/MS System (Applied Biosystems, Foster City, CA) equipped with a TurbolonSpray ESI source and an 1100 Series HPLC System (Agilent, Waldbronn, Germany), as described by Vishwanath et al. (2009). Chromatographic separation was performed at $25^{\circ} \mathrm{C}$ on a $15 \mathrm{~cm}$ Gemini $\mathrm{C}_{18}$-column. The chromatographic methods and chromatographic and MS parameters for the investigated analytes were as described by 
Vishwanath et al. (2009). ESI-MS/MS was performed in time-scheduled MRM mode in both positive and negative polarities in two separate chromatographic runs per sample by scanning two fragmentation reactions per analyte. The MRM detection window of each analyte was set to its expected retention time $\pm 30 \mathrm{~s}$ in positive mode and $\pm 60 \mathrm{~s}$ in negative mode.

\section{Results and Discussion}

\section{Fungal infection rate of the maize batches}

The good-quality batches all had a rate of infected/damaged kernels below $3 \%$ ( $n=100)$, while the rate in mouldy batches was 6-19\%, demonstrating a clear difference in maize quality (Table 1). The average mass of infected and uninfected kernels was $0.29 \mathrm{~g}$ and $0.37 \mathrm{~g}$ ( $\mathrm{n}=14$ each) with a relative standard deviation (RSD) of $14 \%$ and $16 \%$, respectively. The visibly infected or damaged kernels plated on water agar showed a 17\%-83\% Fusarium infection rate (Table 1), with only fumonisin producing Fusaria. Primarily only F. subglutinans and F. verticillioides were found, as previously found in South African maize (Rheeder et al. 1992; van der Westhuizen et al. 2011b). The less heat-tolerant $F$. graminearum was found only once among the randomly selected kernels. Penicillium concavorugulosum was found in four batches, $A$. wentii in three, Eurotium sp. in one, $P$. aurantiogriseum in two, P. crustosum in two, P. pittii in one and P. brevicompactum in one.

\section{Validation of fumonisin extraction}

The three calibration curves from different days had $\mathrm{R}^{2}$-values of $\mathrm{FB}_{1}: 0.9932,0.9986,0.9974$; and $\mathrm{FB}_{2}: 0.9974,0.9978,0.9984$. The RSDs of the slopes were $7.8 \%\left(\mathrm{FB}_{1}\right)$ and $16.1 \%\left(\mathrm{FB}_{2}\right)$. The average RSD of the spiked sample $(n=3)$ for $\mathrm{FB}_{1}$ was $12 \%$ (range: $7.5-19 \%$ ) and for $\mathrm{FB}_{2} 17 \%$ (range: $3.4-$

27\%). The limit of quantification (RSD $<20 \%$ ) was $0.25 \mathrm{mg} / \mathrm{kg}$ for $\mathrm{FB}_{1}$ and $0.081 \mathrm{mg} / \mathrm{kg}$ for $\mathrm{FB}_{2}$. The 
limit of detection (LOD) was estimated to an $\mathrm{s} / \mathrm{n}$ ratio of $5: 1$, giving an $L O D_{\mathrm{FB} 1}$ of $0.16 \mathrm{mg} / \mathrm{kg}$ and $\mathrm{LOD}_{\mathrm{FB} 2}$ of $0.057 \mathrm{mg} / \mathrm{kg}$. The average apparent recovery for $\mathrm{FB}_{1}$ was $121 \%$ with an average RSD of $25 \%$, and for $\mathrm{FB}_{2}$ was $115 \%$ with an average RSD of $20 \%$.

\section{Fumonisin content in single maize kernels}

When single kernels were analyzed for fumonisin, all 10 batches contained positive kernels. Of the 400 tested kernels, 59 (15\%) were positive for fumonisin. Of these, all were positive for $\mathrm{FB}_{1}, \mathrm{FB}_{2}$, $\mathrm{FB}_{3}$, and $\mathrm{FB}_{4}$, except two that did not contain $\mathrm{FB}_{3}$ and $\mathrm{FB}_{4}$. LC-TOF-MS screening of a few highly infected kernels also contained fumonisins $A_{1}, A_{2}, C_{1}, C_{3}$ and $C_{4}$, although in amounts much lower than FBs (data not shown).

None of the maize kernels that were visually characterized as uninfected contained detectable amounts of fumonisins, whereas 3-40\% of the visually infected kernels were contaminated with fumonisins (Table 1). The total fumonisin concentration $\left(\mathrm{FB}_{1}, \mathrm{FB}_{2}, \mathrm{FB}_{3}\right.$ and $\mathrm{FB}_{4}$ ) of single kernels in all the batches was $1.8-1428 \mathrm{mg} / \mathrm{kg}$. Interestingly, the few low-quality kernels sorted from the good-quality cob batches generally had a higher fumonisin content compared to the poor-quality maize. However, kernels that were visually infected were more frequently found in the poorquality cob batches.

Using the infection rate, average kernel weight, batch weight, and average fumonisin concentration, the total fumonisin content in the batches was estimated. The estimated total fumonisin content of the good-quality batches was $0.28-1.1 \mathrm{mg} / \mathrm{kg}$ (average: $0.71 \mathrm{mg} / \mathrm{kg}$ ), while batches characterized as mouldy contained 0.03-6.2 mg/kg fumonisins (average: $2.9 \mathrm{mg} / \mathrm{kg}$ ). This showed a marked difference in the fumonisin content of the high- and low-quality cob batches. 
Of the 10 batches, 2 exceeded the maximum level of $4 \mathrm{mg} / \mathrm{kg}$ recommended by the USFDA in maize for human consumption (US Food and Drug Administration 2001), and 4 exceeded the EU regulatory limit of $1 \mathrm{mg} / \mathrm{kg}$ (EU 2007). The values for fumonisin were similar to previous findings in South African subsistence maize (van der Westhuizen et al. 2008; 2010a). In a previous study van der Westhuizen et al. (2008) found levels of fumonisins in the mouldy maize (as classified on cobs by the farmers) that were higher (mean levels in different areas over two seasons 4.85-12.9 $\mathrm{mg} / \mathrm{kg}$ ) than those found in this study.

\section{Multi-mycotoxin screening of selected kernels}

In the previous analysis, the kernels were only tested for fumonisin, however since only $15 \%$ of the kernels were contaminated with fumonisin, we performed a multi-mycotoxin screening for identification of other toxins from non-fumonisin producing fungi. As well as to investigate the presence of compounds produced be post-harvest fungi e.g. P. concavorugulosum and A. wentii. Eighty kernels were selected and analyzed by the multi-detection method for 186 bacterial and fungal metabolites, as described by Vishwanath et al. (2009), results are shown in table 2. Fumonisins were detected in 50 of the 80 samples (Table 2), and only in 4 of the samples were no microbial metabolites detected. Other frequently detected metabolites were fusaric acid $(n=53)$, emodin ( $n=27)$, chanoclavine $(n=25)$, equisetin $(n=14)$ and fusaproliferin $(n=12)$. Metabolites found in a low number of samples were: agroclavine $(n=3)$, altertoxin-I $(n=3)$, beauvericin $(n=7)$, moniliformin $(n=4)$, nivalenol $(n=4)$, rugulosin $(n=4)$, and tentoxin $(n=3)$. Other metabolites found in single cases were: alternariol, calphostin $\mathrm{C}$, and cyclosporins $\mathrm{A}, \mathrm{C}$ and $\mathrm{H}$. To our knowledge, this is the first report of the fungal metabolites agroclavine, calphostin C, chanoclavine, cyclosporins, 
equisetin, rugulosin and tentoxin, as well as the bacterial metabolites nonactin, monactin, and valinomycin in maize.

Table 3 shows a summary of Table 2 with the suspected producers of the metabolites as supported by mycological examination as well as if the compounds are produced pre or post harvest. Of the detected compounds and mycotoxins, many are presumably produced pre-harvest based on the natural field growth patterns of Alternaria and Fusarium. However, a lower number of toxins, generally considered to be produced post-harvest, were also detected, mostly those originating from Penicillium, Aspergillus and Eurotium. The finding of pre-harvest mycotoxins occurring from several Fusaria in the same maize kernels points toward co-existence of the producers rather than species succession which could explain the remaining compounds originating from several species and genera.

Beauvericin, fusaproliferin and moniliformin (Table 1 ) are metabolites of $F$. subglutinans. Kernels with fusaproliferin and/or moniliformin often showed lower amounts of fumonisins, which could indicate the presence of $F$. subglutinans, which is known to be a poor fumonisin producer (Sala et al. 1994). Furthermore, samples containing fumonisin and fusaric acid had an average fusaric acid content of $37 \mathrm{mg} / \mathrm{kg}$, while visually infected samples without fumonisin had a significantly higher average content of $112 \mathrm{mg} / \mathrm{kg}$. Fusaric acid is a pre-harvest compound, a plant growth inhibitor and suggested to be antifungal and antinematodic (Bacon et al. 1996; Diniz \& Oliveira 2009). Its presence in samples without fumonisins strongly indicates that non-toxinogenic Fusaria were present in the maize, and supports the possibility of using these fungi as biocontrol agents against fumonisin-producing species, as is the case for A. flavus (Abbas et al. 2006; Antilla \& Cotty 2002; Cleveland et al. 2003). 
Equisetin is known to be produced by $F$. equiseti, which also produces nivalenol; however this species was not detected. Nivalenol could also originate from $F$. graminearum, but this species was found only on a single kernel. However, the mycological screening was conducted on only a limited number of kernels, so detecting and isolating a few $F$. equiseti or $F$. graminearum in samples dominated by $F$. verticillioides and F. subglutinans would have been difficult. In addition, different kernels were used for the mycological examination and for chemical analysis. The cyclosporins could have originated from either F. solani or Tolypocladium niveum, both previously described as producers of cyclosporins (Dreyfuss et al. 1976; Isaac et al. 1990; Proksa et al. 1991; Sugiura et al. 1999).

Several Alternaria species can produce alternariol, tentoxin and altertoxin I, and the finding of these compounds was expected since Alternaria spp. grow superficially on many grain types (Andersen et al. 2002). Agroclavine, chanoclavine, and rugulosin indicate that $P$. concavorugulosum (a known producer of these compounds, Frisvad 1989) was present in batches $429,432,438$ and 440 , which was validated by the mycological findings of this species these batches. Emodin is a common metabolite of many Eurotium species and A. wentii (Samson et al. 2010), which are common superficial contaminants on dried grain and were found on some kernels from two good and two mouldy batches. The presence of emodin and chanoclavine in the visually uninfected kernels was not surprising, as growth is superficial and thus easily abraded off the kernels so they appear uninfected. The bacterial metabolites monactin, nonactin and valinomycin were found only once, and in the same sample.

Even though aflatoxins, like fumonisins, are considered important mycotoxins in African maize, no aflatoxins were found in any of the analyzed samples (Shephard 2008). These findings corresponded to the fungal isolation results, which found neither A. flavus nor A. parasiticus from 
any of the 240 kernels surveyed and also to a previous study conducted in the former Transkei region which also did not find any aflatoxin or A. flavus (van der Westhuizen et al. 2011a). This is the first study to examine the mycotoxin profile of single maize kernels. The maize mycotoxin profiles were diverse, and the detection of metabolites from several fungi on single kernels supports the fact that several fungal species can co-occur on a single kernel. Our results showed a low percentage of maize kernels containing fumonisins (15\%), and an even lower percentage $(<4 \%)$ with a high concentration of fumonisins $(>100 \mathrm{mg} / \mathrm{kg})$. The results also confirm that Fusarium mycotoxins are non-homogeneously distributed in maize (van der Westhuizen et al. 2011a). Although fumonisins appeared to be the cause of the most serious mycotoxin problem since they were the most widespread of the analyzed mycotoxins, the fumonisin contamination in our maize samples was mainly caused by a low percentage of highly infected kernels. This support the approach were a more thorough sorting of the subsistence grown maize is performed to decrease the fumonisin concentration. A theoretical calculation of the effect of removing the highly infected kernels (4\%) showed that the average fumonisin concentration decreased by $71 \%$ (data not shown) after a simple sorting. This is a substantial effect gained using a very simple method. The strategy of sorting out visibly infected kernels has recently been successfully applied in an intervention study in the same rural Transkei area (van der Westhuizen et al. 2011). A group of farmers were trained to remove infected kernels from their good-quality maize and achieved a mean fumonisin reduction of $84 \%$ by removing a mean of $3.9 \%$ by weight, which is very close to our estimated reduction (van der Westhuizen et al. 2010b; 2011a; 2011b).

A valuable addition to these results could be to investigate the mycotoxin chemistry in single kernels, while simultaneously conducting an investigation of the mycology of the same kernel, for a better understanding of how species co-exist and how they are spread across the cob. This could 
also determine whether several fungal species infect the same kernel or if kernels are infected with only one species. Furthermore, data on single-kernel mycotoxin content may help in designing sampling plans for detecting mycotoxins in large lots. For example, Whitaker et al. (1972) suggested using a negative binominal distribution and Vargas et al. (2005) showed that approximately 6 coffee beans per 10,000 beans are contaminated if a lot contains $5 \mu \mathrm{g} / \mathrm{kg}$ of ochratoxin A. The results of our single-kernel mycotoxin analysis give an in-depth view of the extent of mycotoxin-producing fungi in South African Transkei subsistence maize, particularly fumonisins. These findings are valuable for designing sampling plans for large maize lots.

Our results support the visual inspection method currently used by the maize-producing farmers and support additional sorting for even more effective removal of mycotoxin-contaminated kernels. Additional mycotoxin reduction might be achieved through biocontrol measures using a non-fumonisin-producing Fusarium strain. Finally the single kernel approach is promising for detecting new fungal compounds in maize, as the concentrations of fungal compounds are much higher in the few infected kernels.

\section{Acknowledgement}

J.M.M. and K.F.N. were funded by the Danish Food Industry Agency (Grant 3304-FVEP-07-730-01). This work was supported by the MYCORED project (EC KBBE-2007-222690-2). 


\section{References}

Abbas HK, Zablotowicz RM, Bruns HA, Abel CA. 2006. Biocontrol of aflatoxin in corn by inoculation with non-aflatoxigenic Aspergillus flavus isolates. Biocontrol Sci Techn. 16:437-449.

Abildgren MP, Lund F, Thrane U, Elmholt S. 1987. Czapek-Dox Agar containing iprodione and dicloran as a selective medium for the isolation of Fusarium species. Lett Appl Microbiol. 5:83-86.

Andersen B, Krøger E, Roberts RG. 2002. Chemical and morphological segregation of Alternaria arborescens, A. infectoria and A. tenuissima species-groups. Mycol Res. 106:170-182.

Antilla L, Cotty PJ. 2002. The ARS-ACRPC partnership to control aflatoxin in Arizona: Current status. Mycopathologia. 155:64.

Bacon CW, Porter JK, Norred WP, Leslie JF. 1996. Production of fusaric acid by Fusarium species. Appl Environ Microbiol. 62:4039-4043.

Chen JP, Mirocha CJ, Xie WP, Hogge L, Olson D. 1992. Production of the mycotoxin fumonisin $B_{1}$ by Alternaria alternata f. sp. Lycopersici. Appl Environ Microbiol. 58:3928-3931.

Cleveland TE, Dowd PF, Desjardins AE, Bhatnagar D, Cotty PJ. 2003. United States Department of Agriculture - Agricultural Research Service research on pre-harvest prevention of mycotoxins and mycotoxigenic fungi in US crops. Pest Manag Sci. 59:629-642.

Diniz SPSS, Oliveira RC. 2009. Effects of fusaric acid on Zea mays L. seedlings. Phyton-Int J Exp Bot. 78:155-160.

Dong YH, Steffenson BJ, Mirocha CJ. 2006. Analysis of ergosterol in single kernel and ground grain by gas chromatography-mass spectrometry. J Agric Food Chem. 54:4121-4125.

Dowell FE, Pearson TC, Maghirang EB, Xie F, Wicklow DT. 2002. Reflectance and transmittance spectroscopy applied to detecting fumonisin in single corn kernels infected with Fusarium verticillioides. Cereal Chem. 79:222-226.

Dreyfuss M, Harri E, Hofmann H, Kobel H, Pache W, Tscherter H. 1976. Cyclosporin-A and C new metabolites from Trichoderma polysporum (Link xx Pers) Rifai. Eur J Appl Microbiol. 3:125-133. 
Commission Regulation 2007/1126/EC of 28 September 2007 amending Regulation (EC) $1881 / 2006$ setting maximum levels for certain contaminants in foodstuffs, regarding Fusarium toxins in maize and maize products. OJ L 255/14-17, 29.09.2007.

Frisvad JC. 1989. The connection between the Penicillia and Aspergilli and mycotoxins with special emphasis on misidentified isolates. Arch Environ Con Tox. 18:452-467.

Frisvad JC, Larsen TO, de Vries R, Meijer M, Houbraken J, Cabanes FJ, Ehrlich K, Samson RA. 2007a. Secondary metabolite profiling, growth profiles and other tools for species recognition and important Aspergillus mycotoxins. Stud Mycol. 59:31-37.

Frisvad JC, Samson RA. 2004. Polyphasic taxonomy of Penicillium subgenus Penicillium - A guide to identification of food and air-borne terverticillate Penicillia and their mycotoxins. Stud Mycol. 49:1-173.

Frisvad JC, Smedsgaard J, Samson RA, Larsen TO, Thrane U. 2007b. Fumonisin $B_{2}$ production by Aspergillus niger. J Agric Food Chem. 55:9727-9732.

Harrison LR, Colvin BM, Greene JT, Newman LE, Cole Jr JR. 1990. Pulmonary edema and hydrothorax in swine produced by fumonisin $\mathrm{B}_{1}$, a toxic metabolite of Fusarium moniliforme. J Vet Diagn Invest. 2:217-221.

Hocking AD, Pitt JI. 1980. Dichloran glycerol medium for enumeration of xerophilic fungi from low moisture foods. Appl Environ Microbiol. 39:488-492.

Isaac CE, Jones A, Pickard MA. 1990. Production of cyclosporins by Tolypocladium niveum strains. Antimicrob Agents Ch. 34:121-127.

Knudsen PB, Mogensen JM, Larsen TO, Nielsen KF. 2010. Occurrence of fumonisins $B_{2}$ and $B_{4}$ in retail raisins. J Agric Food Chem. 59:772-776.

Logrieco A, Doko B, Moretti A, Frisullo S, Visconti A. 1998. Occurrence of fumonisin $B_{1}$ and $B_{2}$ in Fusarium proliferatum infected asparagus plants. J Agric Food Chem, 46:5201-5204. 
Logrieco A, Ferracane R, Visconti A, Ritieni A. 2010. Natural occurrence of fumonisin $B_{2}$ in red wine from Italy. Food Addit Contam A. 27:1136-1141.

Logrieco A, Mule G, Moretti A, Bottalico A. 2002. Toxigenic Fusarium species and mycotoxins associated with maize ear rot in Europe. Eur J Plant Pathol. 108:597-609.

Makaula AN, Marasas WF, Venter FS, Badenhorst CJ, Bradshaw D, Swanevelder S. 1996.

Oesophageal and other cancer patterns in four selected districts of the Transkei, Southern Africa: 1985-1990. Afr J Health Sci. 3:11-15.

Månsson M, Klejnstrup ML, Phipps RK, Nielsen KF, Frisvad JC, Gotfredsen CH, Larsen TO. 2010. Isolation and NMR characterization of fumonisin $\mathrm{B}_{2}$ and a new fumonisin $\mathrm{B}_{6}$ from Aspergillus niger. J Agric Food Chem. 58:949-953.

Maragos C, Busman M. 2010. Rapid and advanced tools for mycotoxin analysis: a review. Food Addit Contam A. 27:688-700.

Marasas WFO. 2001. Discovery and occurrence of the fumonisins: A historical perspective. Environ Health Perspect. 109:239-243.

Marin S, Ramos AJ, Vazquez C, Sanchis V. 2007. Contamination of pine nuts by fumonisin produced by strains of Fusarium proliferatum isolated from Pinus pinea. Lett Appl Microbiol. 44:68-72.

Martins ML, Martins HM, Bernardo F. 2001. Fumonisins $B_{1}$ and $B_{2}$ in black tea and medicinal plants. J Food Prot. 64:1268-1270.

Miller JD. 2008. Mycotoxins in small grains and maize: Old problems, new challenges. Food Addit Contam A. 25:219-230.

Mogensen JM, Moller KA, von FP, Labuda R, Varga E, Sulyok M, Kubatova A, Thrane U, Andersen B, Nielsen KF. 2010a. Production of fumonisins $B_{2}$ and $B_{4}$ in Tolypocladium species. J Ind Microbiol Biotechnol. DOI 10.1007/s10295-010-0916-1.

Mogensen JM, Larsen TO, Nielsen KF. 2010b. Widespread occurence of the mycotoxin fumonisin $\mathrm{B}_{2}$ in wine. J Agric Food Chem. 58:4853-4857. 
Mogensen JM, Frisvad JC, Thrane U, Nielsen KF. 2010c. Production of fumonisin $B_{2}$ and $B_{4}$ by Aspergillus niger on grapes and raisins. J Agric Food Chem. 58:954-958.

Nielsen KF, Smedsgaard J. 2003. Fungal metabolite screening: database of 474 mycotoxins and fungal metabolites for dereplication by standardised liquid chromatography-UV-mass spectrometry methodology. J Chromatogr A. 1002:111-136.

Noonim P, Mahakarnchanakul W, Nielsen KF, Frisvad JC, Samson RA. 2009. Fumonisin $B_{2}$ production by Aspergillus niger from Thai coffee beans. Food Addit Contam A. 26:94-100.

Proksa B, Uhrin D, Kovacik V, Voticky Z, Betina V. 1991. Identity of the antibiotic ramihyphin-A and cyclosporine-A. Folia Microbiol. 36:141-143.

Reddy KRN, Abbas HK, Abel CA, Shier WT, Oliveira CAF, Raghavender CR. 2009. Mycotoxin contamination of commercially important agricultural commodities. Toxin Rev. 28:154-168.

Rheeder JP, Marasas WFO, Thiel PG, Sydenham EW, Shephard GS, Vanschalkwyk DJ. 1992.

Fusarium moniliforme and fumonisins in corn in relation to human esophageal cancer in Transkei. Phytopathology. 82:353-357.

Rheeder JP, Marasas WFO, Vismer HF. 2002. Production of fumonisin analogs by Fusarium species. Appl Environ Microbiol. 68:2101-2105.

Sala N, Sanchis V, Vilaro P, Viladrich R, Torres M, Vinas I, Canela R. 1994. Fumonisin producing capacity of Fusarium strains isolated from cereals in Spain. J Food Prot. 57:915-917.

Samson RA, Hong SB, Frisvad JC. 2006. Old and new concepts of species differentiation in Aspergillus. Med Mycol. 44:S133-S148.

Samson RA, Houbraken J, Thrane U, Frisvad JC, Andersen B. 2010. Food and indoor fungi. Utrecht, The Netherlands: CBS-KNAW Fungal Biodiversity Centre.

Shephard GS. 2008. Risk assessment of aflatoxins in food in Africa. Food Addit Contam A. 25:12461256. 
Shephard GS, Leggott NL, Stockenstrom S, Somdyala NIM, Marasas WFO. 2002. Preparation of South African maize porridge: effect on fumonisin mycotoxin levels. S Afr J Sci. 98:393-396.

Shephard GS, Thiel PG, Stockenstrom S, Sydenham EW. 1996. Worldwide survey of fumonisin contamination of corn and corn-based products. J AOAC Int. 79:671-687.

Sinha RC, Savard ME. 1997. Concentration of deoxynivalenol in single kernels and various tissues of wheat heads. Can J Plant Pathol. 19:8-12.

Solfrizzo M, De Girolamo A, Vitti C, Tylkowska K, Grabarkiewicz-Szczesna J, Szopinska D, Dorna H. 2005. Toxigenic profile of Alternaria alternata and Alternaria radicina occurring on umbelliferous plants. Food Addit Contam A. 22:302-308.

Sørensen JL, Mogensen JM, Thrane U, Andersen B. 2009. Potato carrot agar with manganese as an isolation medium for Alternaria, Epicoccum and Phoma. Int J Food Microbiol. 130:22-26.

Sugiura Y, Barr JR, Barr DB, Brock JW, Elie CM, Ueno Y, Patterson DG, Potter ME, Reiss E. 1999. Physiological characteristics and mycotoxins of human clinical isolates of Fusarium species. Mycol Res. 103:1462-1468.

Sydenham EW, Shephard GS, Thiel PG, Marasas WFO, Stockenstrom S. 1991. Fumonisin contamination of commercial corn-based human foodstuffs. J Agric Food Chem. 39:2014-2018.

Thiel PG, Shephard GS, Sydenham EW, Marasas WFO, Nelson PE, Wilson TM. 1991. Levels of fumonisin $B_{1}$ and fumonisin $B_{2}$ in feeds associated with confirmed cases of equine leukoencephalomalacia. J Agric Food Chem. 39:109-111.

U.S.Food and Drug Administration. 2001. Guidance for Industry: Fumonisin levels in human foods and animal feeds. United States Food and Drug Administration, Washington DC.

van der Westhuizen L, Shepard GS, Rheeder JP, Burger HM, Gelderblom WC, Wild CP, Gong YY. 2011a. Fumonisin $B_{1}$ as a urinary biomarker of exposure in a maize intervention study among South African subsistence farmers. Cancer Epidem Biomar. 20:483-489. 
van der Westhuizen L, Shephard GS, Rheeder JP, Burger HM. 2010a. Individual fumonisin exposure and sphingoid base levels in rural populations consuming maize in South Africa. Food Chem Toxicol. 48:1698-1703.

van der Westhuizen L, Shephard GS, Rheeder JP, Burger HM, Gelderblom WCA, Wild CP, Gong YY. 2010b. Simple intervention method to reduce fumonisin exposure in a subsistence maize-farming community in South Africa. Food Addit Contam A. 27:1582-1588.

van der Westhuizen L, Shephard GS, Rheeder JP, Burger HM, Gelderblom WCA, Wild CP, Gong YY. 2011b. Optimising sorting and washing of home-grown maize to reduce fumonisin contamination under laboratory-controlled conditions. Food Control. 22:396-400.

van der Westhuizen L, Shephard GS, Rheeder JP, Somdyala NIM, Marasas WFO. 2008. Sphingoid base levels in humans consuming fumonisin-contaminated maize in rural areas of the former Transkei, South Africa: a cross-sectional study. Food Addit Contam A. 25:1385-1391.

Vargas EA, Whitaker TB, dos Santos EA, Slate AB, Lima FB, Franca RCA. 2005. Testing green coffee for ochratoxin A, part II: Observed distribution of ochratoxin A test results. J AOAC Int. 88:780-787.

Vishwanath V, Sulyok M, Labuda R, Bicker W, Krska R. 2009. Simultaneous determination of 186 fungal and bacterial metabolites in indoor matrices by liquid chromatography/tandem mass spectrometry. Anal Bioanal Chem. 395:1355-1372.

Whitaker TB, Wiser EH, Dickens JW, Monroe RJ. 1972. Comparison of observed distribution of aflatoxin in shelled peanuts to negative binomial distribution. J Am Oil Chem Soc. 49:590-593.

Wulff EG, Sorensen JL, Lubeck M, Nielsen KF, Thrane U, Torp J. 2010. Fusarium spp. associated with rice Bakanae: ecology, genetic diversity, pathogenicity and toxigenicity. Environ Microbiol. $12: 649-657$.

Yazar S, Omurtag GZ. 2008. Fumonisins, trichothecenes and zearalenone in cereals. Int J Mol Sci. 9:2062-2090. 
Table 1: Infection rate of batches and fumonisin (FB) content in uninfected and infected maize kernels $\left(\mathrm{n}_{\text {total }}=400\right)$.

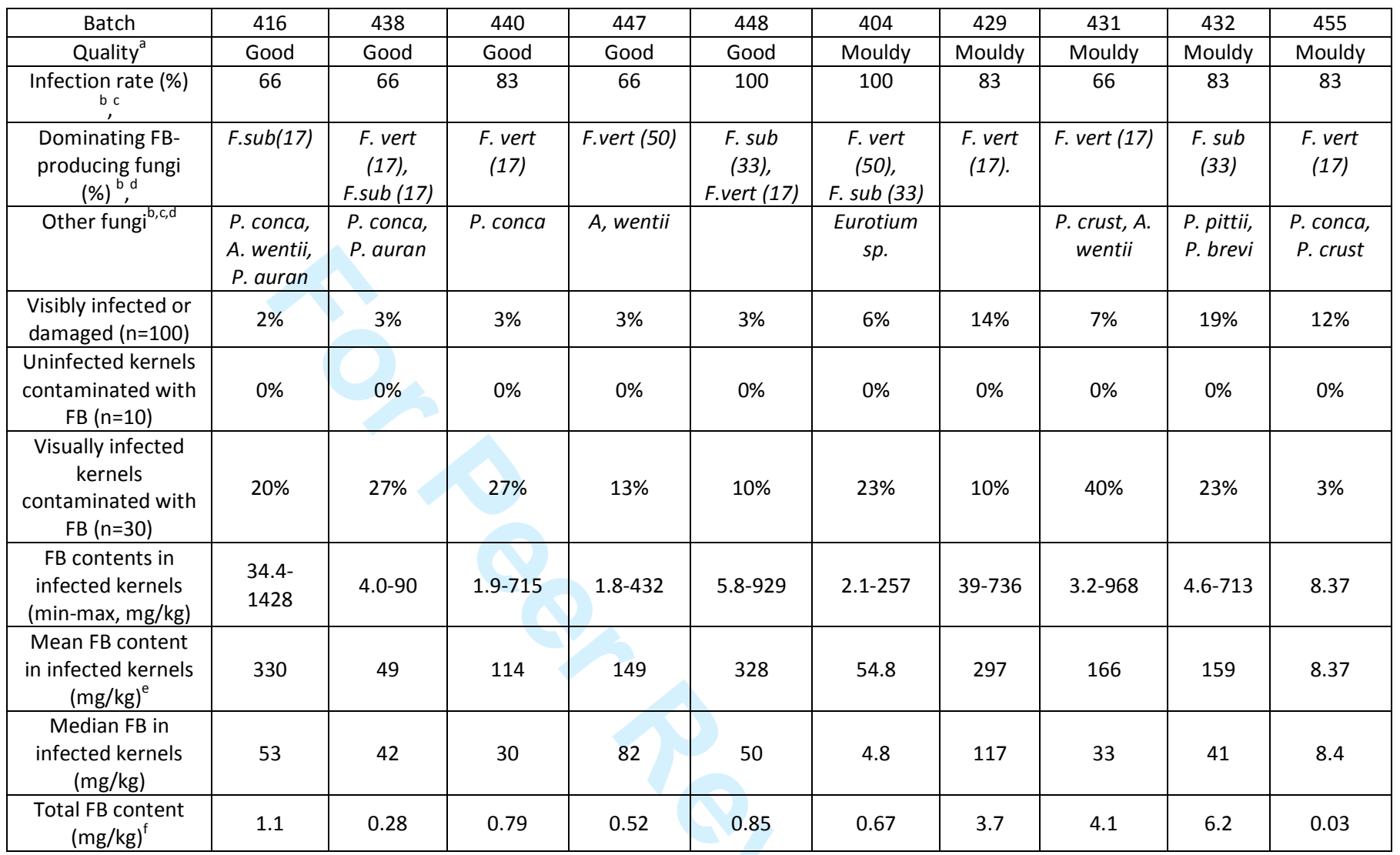

Note: Fumonisin content is the total $\mathrm{FB}_{1}, \mathrm{FB}_{2}, \mathrm{FB}_{3}$ and $\mathrm{FB}_{4}$ content.

Abbreviations: F. vert: F. verticillioides; F. sub: F. subglutinans; P. auran.: P. aurantiogriseum; P. brevi: P. brevicompactum; P. conca:

P. concavurugulosum; P. crust.: P. crustosum.

${ }^{\text {a }}$ As sorted by the five subsistence farmers.

${ }^{\mathrm{b}}$ Surface sterilization in hypochlorite prior to plating for a total of 180 randomly selected kernels (18 per batch with 6 on DG18\%, 6

on CZID, and 6 on PCMA).

${ }^{\mathrm{c}}$ Plating of 60 visibly infected or damaged kernels on water agar per batch.

${ }^{d}$ Not including sterile mycelia and species found only once among the 240 kernels.

${ }^{\mathrm{e}} \mathrm{LC}-\mathrm{MS} / \mathrm{MS}$ on Ultima QQQ. $\mathrm{LOD}_{\mathrm{FB} 1}$ of $0.16 \mathrm{mg} / \mathrm{kg}$ and $\mathrm{LOD}_{\mathrm{FB} 2}$ of $0.057 \mathrm{mg} / \mathrm{kg}$

${ }^{\mathrm{f}}$ Total FB content were calculated from the infection rate, mean kernel weight, batch weight, and mean fumonisin concentration. 
Table 2: Fungal and bacterial metabolites in single maize kernels by multi-detection MS/MS analysis.

\begin{tabular}{|c|c|c|c|c|c|c|c|c|c|c|c|}
\hline Batch & $\begin{array}{c}\text { Maize } \\
\text { quality* }\end{array}$ & $\begin{array}{c}\text { Sample } \\
\text { no. }\end{array}$ & $\begin{array}{c}\mathrm{FB}_{1} \\
\mathrm{mg} / \mathrm{kg}\end{array}$ & $\begin{array}{c}\mathrm{FB}_{2} \\
\mathrm{mg} / \mathrm{kg}\end{array}$ & $\begin{array}{c}\mathrm{FB}_{3} \\
\mathrm{mg} / \mathrm{kg}\end{array}$ & $\begin{array}{c}\mathrm{FB}_{4} \\
\mathrm{mg} / \mathrm{kg}\end{array}$ & $\begin{array}{l}\text { Fusaric } \\
\text { acid } \\
\mathrm{mg} / \mathrm{kg}\end{array}$ & $\begin{array}{c}\text { Equisetin } \\
\mu \mathrm{g} / \mathrm{kg}\end{array}$ & $\begin{array}{c}\text { Chanocla } \\
\text { vine } \\
\mu \mathrm{g} / \mathrm{kg}\end{array}$ & $\begin{array}{c}\text { Emodin } \\
\mu \mathrm{g} / \mathrm{kg}\end{array}$ & Other compounds \\
\hline \multirow[t]{5}{*}{416} & \multirow[t]{5}{*}{ Good } & 2486 & 3.03 & 0.53 & 0.38 & 0.17 & 1.9 & - & - & - & \\
\hline & & 2489 & - & - & - & - & - & - & 4.6 & - & \\
\hline & & 2491 & 94 & 39 & 8.5 & 8.8 & 8.1 & 68 & - & - & \\
\hline & & 2502 & 1910 & 866 & 167 & 127 & 7.3 & 55 & - & - & $\begin{array}{l}\text { Beauvericin, } \\
\text { Nivalenol }\end{array}$ \\
\hline & & 2506 & 747 & 246 & 71 & 55 & 17 & 35 & 0.78 & - & $\begin{array}{l}\text { Beauvericin, } \\
\text { Nivalenol }\end{array}$ \\
\hline \multirow[t]{9}{*}{438} & \multirow[t]{9}{*}{ Good } & 2527 & 9.3 & 2.9 & 1.1 & 0.57 & 17 & - & 0.53 & - & \\
\hline & & 2529 & 46 & 43 & 1.3 & 4.4 & 16 & - & 83 & 6.1 & $\begin{array}{l}\text { Agroclavine, } \\
\text { Rugulosin }\end{array}$ \\
\hline & & 2531 & 21 & 8 & 2.9 & 2 & 12 & - & - & 9.2 & $\begin{array}{l}\text { Fusaproliferin, } \\
\text { Alternariol }\end{array}$ \\
\hline & & 2533 & - & 0.14 & - & - & 46 & - & - & 18 & Fusaproliferin \\
\hline & & 2535 & - & - & - & - & 212 & 14 & 15 & - & $\begin{array}{l}\text { Fusaproliferin, } \\
\text { Monactin, Nonactin, } \\
\text { Valinomycin }\end{array}$ \\
\hline & & 2543 & 0.07 & - & - & - & 125 & - & - & 3.7 & Altertoxin-I \\
\hline & & 2545 & - & - & - & - & - & 7756 & - & - & \begin{tabular}{|l} 
Fusaproliferin, \\
Beauvericin, \\
Nivalenol, Tentoxin \\
\end{tabular} \\
\hline & & 2546 & 149 & 26 & 6.8 & 4 & 26 & - & 0.52 & - & Fusaproliferin \\
\hline & & 2550 & 48 & 16 & 7.8 & 4.4 & 24 & - & - & - & $3=$ \\
\hline \multirow[t]{8}{*}{440} & \multirow[t]{8}{*}{ Good } & 2558 & - & - & - & - & 0.2 & - & - & 7.3 & 8 \\
\hline & & 2566 & - & - & - & - & - & - & - & - & $\rightarrow$ \\
\hline & & 2567 & 0.18 & 0.062 & - & - & - & 218 & 1.3 & - & \\
\hline & & 2582 & 794 & 221 & 43 & 31 & 31 & - & 5.6 & 6.8 & Rugulosin \\
\hline & & 2584 & 4.7 & 1.2 & 0.61 & 0.34 & 63 & - & 6 & - & \\
\hline & & 2586 & - & - & - & - & 5.1 & - & 0.82 & - & \\
\hline & & 2591 & 37 & 11 & 4.2 & 2.9 & 12 & - & - & 35 & \\
\hline & & 2592 & 34 & 13 & 2.9 & 2.2 & 2.8 & - & - & - & \\
\hline 447 & Good & 2603 & - & 0.033 & - & - & - & - & - & - & \\
\hline
\end{tabular}




\begin{tabular}{|c|c|c|c|c|c|c|c|c|c|c|c|}
\hline & & 2619 & 2.6 & 0.76 & 0.59 & 0.43 & 24 & - & - & - & \\
\hline & & 2622 & - & - & - & - & - & - & - & - & \\
\hline & & 2626 & - & - & - & - & - & - & - & - & \\
\hline & & 2629 & 730 & 203 & 47 & 26 & 1.7 & - & - & 46 & Beauvericin \\
\hline & & 2632 & - & - & - & - & 1.2 & - & - & 9.7 & \\
\hline & & 2633 & - & - & - & - & - & - & - & - & \\
\hline \multirow[t]{6}{*}{448} & \multirow[t]{6}{*}{ Good } & 2644 & - & - & - & - & - & - & - & 12 & $\begin{array}{l}\text { Beauvericin, } \\
\text { Tentoxin, Altertoxin- } \\
\text { I }\end{array}$ \\
\hline & & 2647 & 5.6 & 0.26 & 0.6 & - & 4.7 & 1691 & - & - & Moniliformin \\
\hline & & 2649 & 1137 & 481 & 84 & 74 & 38 & - & 1 & - & \\
\hline & & 2652 & 0.58 & 0.08 & - & - & - & - & - & - & $\begin{array}{l}\text { Fusaproliferin, } \\
\text { Moniliformin }\end{array}$ \\
\hline & & 2659 & - & - & - & - & 165 & - & 5.9 & 3.9 & Fusaproliferin \\
\hline & & 2665 & - & - & - & - & 73 & 12 & - & - & \\
\hline \multirow[t]{7}{*}{404} & \multirow[t]{7}{*}{ Mouldy } & 2681 & - & - & - & - & - & 1939 & 1.1 & 10 & Cyclosporins A, C, H \\
\hline & & 2687 & 206 & 72 & 13 & 11 & 25 & - & 3.8 & - & \\
\hline & & 2696 & 3 & 0.74 & 0.28 & - & 8.1 & - & - & - & \\
\hline & & 2699 & 1.8 & 0.57 & 0.2 & 0.0058 & - & - & - & - & Fusaproliferin \\
\hline & & 2704 & - & - & - & - & 40 & - & - & - & \\
\hline & & 2706 & - & 0.038 & - & - & - & - & - & - & \\
\hline & & 2708 & 78 & 32 & 12 & 6.4 & 2.4 & - & - & - & \\
\hline \multirow[t]{7}{*}{429} & \multirow[t]{7}{*}{ Mouldy } & 2720 & - & - & - & - & - & - & 0.63 & 14 & $r$ \\
\hline & & 2727 & - & - & - & - & 1.0 & - & - & 36 & \\
\hline & & 2728 & - & - & - & - & - & - & 2.1 & - & 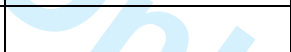 \\
\hline & & 2730 & 886 & 385 & 20 & 20 & 4.4 & - & - & - & $\sqrt{2+3 x}$ \\
\hline & & 2738 & 158 & 27 & 7.1 & 3.4 & 26 & - & - & 17 & Rugulosin \\
\hline & & 2741 & - & - & - & - & - & - & - & 16 & 5 \\
\hline & & 2745 & - & - & - & - & 21 & - & - & - & \\
\hline \multirow[t]{4}{*}{431} & \multirow[t]{4}{*}{ Mouldy } & 2758 & - & - & - & - & - & 33 & 126 & 4.4 & Agroclavine \\
\hline & & 2766 & 1277 & 361 & 47 & 21 & 0.2 & - & 1.1 & - & \\
\hline & & 2767 & 2.4 & 0.64 & 0.25 & 0.0076 & 16 & - & - & - & \\
\hline & & 2768 & 8.5 & 1.9 & 0.61 & 0.39 & 0.4 & - & 0.59 & - & \\
\hline
\end{tabular}




\begin{tabular}{|c|c|c|c|c|c|c|c|c|c|c|c|}
\hline & & 2776 & - & - & - & - & - & - & 2.5 & 6.2 & Fusaproliferin \\
\hline & & 2781 & - & - & - & - & 23 & 24 & 1.5 & - & \\
\hline & & 2782 & 265 & 39 & 31 & 14 & 4.0 & - & 13 & 3.3 & Fusaproliferin \\
\hline & & 2784 & 932 & 254 & 47 & 34 & 55 & - & - & - & $\begin{array}{l}\text { Beauvericin, } \\
\text { Moniliformin }\end{array}$ \\
\hline & & 2792 & 51 & 14 & 6.7 & 3.9 & 8.4 & - & 0.04 & - & \\
\hline \multirow[t]{13}{*}{432} & \multirow[t]{13}{*}{ Mouldy } & 2798 & - & - & - & - & - & - & - & - & Nivalenol \\
\hline & & 2807 & 0.43 & 0.13 & - & - & 0.8 & - & 106 & 75 & $\begin{array}{l}\text { Fusaproliferin, } \\
\text { Agroclavine, } \\
\text { Altertoxin-I, } \\
\text { Rugulosin }\end{array}$ \\
\hline & & 2810 & - & - & - & - & 251 & - & - & 5.2 & \\
\hline & & 2815 & - & 0.041 & - & - & - & - & - & - & \\
\hline & & 2817 & - & - & - & - & - & 101 & - & - & Tentoxin \\
\hline & & 2820 & 30 & 22 & 4.6 & 9 & 23 & - & - & - & \\
\hline & & 2821 & 15 & 9 & 1.5 & 2.1 & 6.6 & - & - & 9.5 & \\
\hline & & 2822 & - & - & - & - & - & - & - & 14 & Moniliformin \\
\hline & & 2825 & - & - & - & - & - & - & - & - & Calphostin C \\
\hline & & 2826 & 739 & 306 & 83 & 92 & 13 & 24 & - & - & \\
\hline & & 2828 & 226 & 90 & 23 & 25 & 22 & - & - & - & Beauvericin \\
\hline & & 2829 & 3.5 & 2.1 & 0.31 & 0.32 & 17 & - & - & - & \\
\hline & & 2833 & 4 & 2.9 & 0.61 & 1.3 & 2.0 & - & - & $1-$ & \\
\hline \multirow[t]{9}{*}{455} & \multirow[t]{9}{*}{ Mouldy } & 2839 & - & - & - & - & - & - & - & 3.5 & 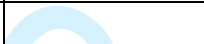 \\
\hline & & 2847 & 0.47 & 0.35 & 0.14 & 0.18 & 0.6 & - & - & 8.9 & 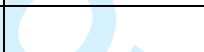 \\
\hline & & 2855 & - & - & - & - & - & - & 0.46 & - & $x^{2}+x^{2}$ \\
\hline & & 2856 & 1.1 & 0.16 & - & - & 49 & - & - & - & 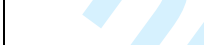 \\
\hline & & 2858 & 0.1 & 0.056 & - & - & - & - & - & - & $\bar{T}$ \\
\hline & & 2860 & 5.9 & 1.2 & 0.74 & 0.35 & 29 & - & - & - & \\
\hline & & 2865 & - & 0.031 & - & - & 27 & - & - & 169 & \\
\hline & & 2868 & - & 0.036 & - & - & - & 709 & - & 58 & Fusaproliferin \\
\hline & & 2872 & - & 0.041 & - & - & 189 & - & - & - & \\
\hline
\end{tabular}

- indicates that the levels were below level of detection

* As sorted by the five subsistence farmers 
Table 3: Distribution and likely producer of metabolites found in visual infected and uninfected kernels.

\begin{tabular}{|c|c|c|c|c|c|}
\hline Mycotoxin & $\begin{array}{c}\% \text { in } \\
\text { uninfected } \\
\text { kernels } \\
(n=8)\end{array}$ & $\begin{array}{c}\% \text { in } \\
\text { infected } \\
\text { kernels } \\
(n=72)\end{array}$ & Likely producer & $\begin{array}{c}\text { Supported } \\
\text { by } \\
\text { microbiology }\end{array}$ & $\begin{array}{c}\text { Produced } \\
\text { pre or post } \\
\text { harvest }\end{array}$ \\
\hline Alternariol & 0 & 1 & Alternaria & No & Pre $^{a}$ \\
\hline Altertoxin-I & 13 & 3 & Alternaria & No & Pre $^{a}$ \\
\hline Beauvericin & 13 & 8 & F. subglutinans & Yes & Pre \\
\hline Calphostin C & 0 & 1 & Cladosporium & No & Pre $^{a}$ \\
\hline Cyclosporin A, C and H & 13 & 0 & F. solani or Tolypocladium & No & Pre \\
\hline Equisetin & 25 & 17 & F. equiseti & No & Pre \\
\hline Fumonisin $B_{1}$ & 0 & 60 & F. verticillioides, F. subglutinans & Yes & Pre \\
\hline Fumonisin $B_{2}$ & 13 & 65 & F. verticillioides, F. subglutinans & Yes & Pre \\
\hline Fumonisin $B_{3}$ & 0 & 51 & F. verticillioides, F. subglutinans & Yes & Pre \\
\hline Fumonisin $B_{4}$ & 0 & 49 & F. verticillioides, F. subglutinans & Yes & Pre \\
\hline Fusaproliferin & 0 & 17 & F. subglutinans & Yes & Pre \\
\hline Fusaric acid & 13 & 64 & $\begin{array}{l}\text { F. verticillioides, F. subglutinans } \\
\text { and other related }\end{array}$ & Yes & Pre \\
\hline Moniliformin & 0 & 6 & F. subglutinans & Yes & Pre \\
\hline Nivalenol & 13 & 4 & F. equiseti, F. graminearum & $(\text { Yes) })^{b}$ & Pre \\
\hline Tentoxin & 13 & 3 & Alternaria & No & Pre $^{a}$ \\
\hline Agroclavin & 13 & 3 & P. concavurugulosum & Yes & Post \\
\hline Chanoclavine & 38 & 31 & P. concavurugulosum & Yes & Post \\
\hline Emodin & 75 & 29 & Eurotium, A. wentii & Yes & Post \\
\hline Rugulosin & 0 & 6 & P. concavurugulosum & Yes & Post \\
\hline
\end{tabular}

${ }^{a}$ As superficial growth usually close to harvest

${ }^{b}$ F. graminearum was only found on a single kernel 